PLANT PATHOGENS

AND THEIR

CONTROL IN HORTICULTURE 


\section{Science in Horticulture Series}

General Editor: L. Broadbent, Emeritus Professor of Biology and Horticulture, University of Bath

Published in collaboration with the Royal Horticultural Society and the Horticultural Education Association.

This series of texts has been designed for students on courses in horticulture at the Higher Diploma or National Diploma level, but care has been taken to ensure that they are neither too specialised for lower-level courses, nor too superficial for university work.

All the contributors to the series have had experience in the horticultural industry and/or education. Consequently, the books have a strong practical flavour which should reinforce their value as textbooks and also make them of interest to a wide audience, including growers and farmers, extension officers, research workers and workers in the agro-chemical, marketing and allied industries, and the many gardeners who are interested in the science behind their hobby.

The authors are all British but they have illustrated their books with examples drawn from many countries. As a result the texts should be of value to English-speaking students of horticulture throughout the world.

Other titles in the series are:

J. K. A. Bleasdale, Plant Physiology in Relation to Horticulture, second edition
A. W. Flegmann and R. A. T. George, Soils and Other Growth Media
S. D. Holdsworth, The Preservation of Fruit and Vegetable Food Products
C. North, Plant Breeding and Genetics in Horticulture
M. J. Sargent, Economics in Horticulture
R. J. Stephens, Theory and Practice of Weed Control
E. J. Winter, Water, Soil and the Plant 


\title{
PLANT PATHOGENS AND THEIR CONTROL IN HORTICULTURE
}

\section{G. R. Dixon}

\author{
B.Sc. (Horticulture), Ph.D. \\ Head of Horticultural Division, \\ School of Agriculture, Aberdeen, UK
}

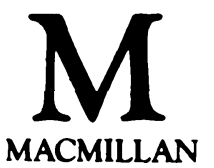


(C) G. R. Dixon 1984

All rights reserved. No part of this publication may be reproduced or transmitted, in any form or by any means, without permission.

First published 1984 by

Higher and Further Education Division

MACMILLAN PUBLISHERS LTD

London and Basingstoke

Companies and representatives

throughout the world

Typeset by

RDL ARTSET LTD, SUTTON, SURREY

British Library Cataloguing in Publication Data

Dixon, G. R.

Plant pathogens and their control in horticulture

ISBN 978-0-333-35912-9

ISBN 978-1-349-06923-1 (eBook)

DOI 10.1007/978-1-349-06923-1 


\section{CONTENTS}

$\begin{array}{ll}\text { Preface } & \text { ix }\end{array}$

1 Pathogens and Diseases 1

1.1 Crop Losses Caused by Pathogens 1

1.2 Host-Pathogen Relationships 4

1.3 Forms of Disease Expression 4

1.3.1 Host expression $\quad 6$

1.3.2 Pathogen expression $\quad 8$

References 9

Further Reading 9

2 Fungi 10

2.1 The Nature of Fungi 10

2.2 Fungal Reproduction 11

2.2.1 Asexual reproduction $\quad 12$

2.2.2 Sexual reproduction 14

2.3 Dispersal and Perennation 15

2.4 Effects of Fungi on Host Plants $\quad 19$

2.5 Fungal Classification 20

2.6 Examples of Plant-Pathogenic Fungi 20

2.6.1 Plasmodiophora brassicae - the cause of clubroot in crucifers 20

2.6.2 Phytophthora infestans-a cause of blight in
potato and tomato

2.6.3 Bremia lactucae - downy mildew of lettuce 29

2.6.4 Sclerotinia fuckeliana (stat. conid. Botrytis cinerea)-the cause of grey mould rotting and dieback of many crops

2.6.5 Venturia inaequalis - the cause of apple scab 38

2.6.6 Sphaerotheca pannosa-powdery mildew of rose $\quad 43$

2.6.7 Armillaria (Armillariella) mellea (honey fungus)a cause of dieback, root and butt rot of many tree and shrub spp.

2.6.8 Cronartium ribicola-blister rust of Pinus and Ribes spp. 
2.6.9 Verticillium albo-atrum and $V$. dahliae-causes

References of vascular wilt diseases in a range of crops $\quad 56$

Further Reading

3 Viruses

3.1 The Nature of Viruses $\quad 65$

3.2 Virus Transmission 67

3.3 Effects of Virus Infection on Host Plants 73

3.4 Virus Classification $\quad 77$

3.5 Examples of Plant-Pathogenic Viruses and Their Modes of Spread

3.5.1 Cauliflower Mosaic Virus (CaMV)-spread by insects (aphids)

3.5.2 Lettuce Mosaic Virus (LMV)--spread by seed

3.5.3 Lettuce Big Vein (LBV) Organism-spread by a fungus

3.5.4 Raspberry Ringspot Virus (RRV)-spread by nematodes

3.5.5 Carnation Mottle Virus (CarMV) - spread by manual handling

3.5.6 Apple Mosaic Virus (AMV)-spread by vegetative propagation

References

Further Reading

4 Bacteria

4.1 The Nature of Bacteria

4.2 Effects of Bacterial Infection on Host Plants 89

4.3 Survival and Spread 97

4.4 Bacterial Classification

4.5 An Example of a Plant-Pathogenic Bacterium-

Pseudomonas phaseolicola-the Cause of Halo-

Blight in Phaseolus Bean

References

Further Reading

5 Control: Host Resistance

5.1 Forms of Pathogen Control

5.2 The Description of Resistance

5.3 Modes of Inheritance

5.4 The Effect of Variation within the Pathogen Population 115

5.5 Host-Parasite Interaction

5.6 Vertical and Horizontal Resistance 
5.7 Sources of Resistance

5.8 The Use of Resistance in Horticultural Crops $\quad 126$

References

Further Reading

6 Control: Chemicals

6.1 General Principles $\quad 136$

6.2 Chemical Nomenclature 138

6.3 The Evolution of Fungicides and Bactericides 139

6.3.1 Inorganic materials 139

6.3.2 Non-specific organic materials $\quad 140$

6.3.3 Specific organic materials $\quad 141$

6.4 Modes of Use 143

6.4.1 Liquid sprays 143

6.4.2 Dusts, granules and seed dressings $\quad 146$

6.4.3 Soil fumigants 148

6.4.4 Smokes and fogs 151

6.5 Modes of Fungicide and Bactericide Action 152

6.6 Pathogen Tolerance to Chemicals 156

6.6.1 Types of tolerance 157

6.7 Economics of Chemical Application 159

6.8 Regulation and Approval of Chemicals 162

References $\quad 166$

$\begin{array}{ll}\text { Further Reading } & 169\end{array}$

7 Control: Spray Application 172

7.1 Main Components of Conventional Sprayers 172

7.1.1 Tank 173

$\begin{array}{ll}\text { 7.1.2 Pumps } & 173\end{array}$

$\begin{array}{ll}\text { 7.1.3 Pressure gauge } & 174\end{array}$

$\begin{array}{ll}7.1 .4 \text { Nozzles } & 174\end{array}$

$\begin{array}{ll}7.1 .5 \text { Booms } & 177\end{array}$

7.1.6 Fans 181

7.2 Improving the Effectiveness of Spraying 181

7.2.1 Objectives 181

7.2.2 Machine calibration $\quad 183$

7.2.3 Retention and drift $\quad 183$

7.2.4 Volume and droplet size $\quad 184$

7.2.5 Electrodynamic application $\quad 190$

7.2.6 Electronic control of sprayers 191

References

Further Reading 
8 Control: Plant Health Regulation

8.1 Phytosanitary Inspections and Quarantine 196

8.2 Certification Schemes 198

8.2.1 Vegetative Planting Material 198

8.2.2 Seed Certification 199

8.3 Eradication and Containment 200

Reference 201

Further Reading 201

9 Control: Cultural and Biological Methods 202

9.1 Fungi and Bacteria 202

9.1.1 Environment 202

9.1.2 Land use $\quad 210$

9.1.3 Crop habit 212

9.1.4 Crop sanitation 213

9.1.5 Biological control 214

9.1.6 Integrated control 216

9.2 Viruses 216

9.2.1 Virus-tested planting material 217

9.2.2 Prevention of spread into and within crops $\quad 217$

References

221

Further Reading $\quad 225$

10 Control: Post-Harvest Pathogens 227

10.1 Pathogens Associated with Post-Harvest Losses 227

10.2 Objectives of Storage 228

10.3 Supplementary Techniques 228

10.3.1 Careful handling and protective packaging 228

10.3.2 Inducing wound barriers 229

10.3.3 Modified atmospheres $\quad 229$

10.3.4 Hypobaric storage 229

10.3.5 Manipulation of relative humidity 229

10.3.6 Heat treatment 230

10.4 Application of Chemicals After Harvest 230

References $\quad 232$

Further Reading 233

Host Index 234

Micro-organism and Disease Index 239

General Index 246 


\section{PREFACE}

This book describes the application of plant pathology to horticulture. In such a context, control of plant pathogens is viewed as an integral part of crop production. From this point of view, the primary requirement is to produce fruitful, high-yielding crops in the most cost-effective manner rather than simply to control plant pathogens. Cost-effectiveness, however, needs careful definition so that long-lasting effects are achieved with minimal and acceptable disturbance to our environment. This requires knowledge of pathogen biology and of the pros and cons of specific control methods. For this reason the book is divided into two main sections. The first four chapters describe those groups of micro-organism that cause disease; these are accompanied by examples of particular fungal, viral and bacterial pathogens. Chapters 5-10 describe control by means of host resistance, chemicals and spray application, plant health regulation, husbandry and biological methods and control in the post-harvest phase. The examples of pathogens given in chapters 2-4 are expanded upon in chapters 5-10. To achieve this there is cross-referencing between chapters and particular terms are highlighted within the text in order to provide readers with readily available definitions. Inevitably in a short book, simplifications are essential; these may offend the pedant but provide the student reader with basic information. On this he or she can build and delve more deeply into facets of plant pathology. The latter purpose is served by extensive lists of references and further reading. Examples of plant pathogens have been limited but reflect the importance of particular groups such that there are several thousand fungi, several hundred viruses and only one or two hundred bacteria pathogenic to crop plants.

Books in the Science in Horticulture Series are intended for a wide range of students from diploma to undergraduate status. While this book is intended for students of horticulture it will also be valuable for those taking plant pathology and microbiology modules in agriculture, botany and forestry courses. The wider audience of growers, advisers, researchers in related fields and knowledgeable amateurs is provided with an up-to-date account of plant disease control. To help readers, some topics are broken down into short subsections in order to convey the gist of a subject area.

Valuable comments and criticism on all or part of this text have been made by: Professor L. Broadbent (Series Editor), Dr S. A. Hill, Dr P. 
Howell, Mr D. R. Humphreys-Jones, Mr A. D. McKelvie, Dr A. Paton, Mr E. B. Scragg, Dr M. Shaw, Dr S. Wale and Dr A. J. Whalley. All errors and omissions are my own fault. Several essential sources of reference have been provided by $\operatorname{Dr} D$. M. Spencer. I record my thanks to those who have so freely provided illustrations; specific acknowledgements are given at appropriate points in the text. I am especially grateful to Mrs M. Sinclair who has cheerfully and efficiently typed my longhand into intelligible script; Mrs A Park and Mrs M. Forbes have provided great assistance in tracing reference material. Particular thanks are due to my wife, Kathy, and to Lucy and Richard for their forbearance and understanding during the preparation of this book. Staff at the Macmillan Press, especially Mr M. J. Stewart, have been a constant source of help and encouragement. 